\title{
Estimates of the frequency of chromosome abnormalities detectable in unselected newborns using moderate levels of banding
}

\author{
Patricia A Jacobs, Caroline Browne, Nina Gregson, Christine Joyce, Helen White
}

\begin{abstract}
Data on structural chromosome abnormalities identified during prenatal diagnosis were used to estimate the number of such abnormalities that would be detectable in an unselected series of newborns using moderate levels of banding ( 400 to 500 bands). These estimates were compared with the rates detected in nonbanded surveys of newborns.

Between 1976 and 1990 prenatal diagnosis using banding techniques was carried out in our laboratory on 14677 women aged 35 and over. Among these, we detected 112 structural rearrangements, 32 unbalanced and 80 balanced. These figures were adjusted by two methods to give an estimate of the frequency of structural abnormalities in the newborn. Our data suggest that the use of moderate levels of banding increases the frequency of unbalanced structural abnormalities from 0.052 to $0.061 \%$ and of balanced structural abnormalities from 0.212 to $0.522 \%$. Thus, the total number of chromosome abnormalities detectable in the newborn is increased from $0.60 \%$ in unbanded preparations to $0.92 \%$ in banded preparations.
\end{abstract}

Virtually all information on the incidence of chromosome abnormalities in liveborn populations is based on the large surveys of unselected newborns carried out in the 1960s. Six large surveys were done at that time and the chromosomes of 56952 newborn babies examined. The results of these studies have been summarised by Hook and Hamerton. ${ }^{1}$ All six surveys were carried out before the introduction of banding techniques and, therefore, while the information on numerical aberrations is still applicable, that on structural abnormalities represents only those abnormalities detected using non-banding techniques. It is reasonable to suppose that, with the exception of Robertsonian translocations and supernumerary marker chromosomes, all categories of structural rearrangements are seriously underrepresented and some, such as paracentric inversions which rely on banding for their detection, completely absent.

More recently, four surveys of the chromosomes of unselected newborns in which banding techniques were used have been published..$^{2-5}$ The rates of structural chromosome abnormalities among the 10253 infants examined in these four studies are considerably greater than those seen in the non-banded surveys.

Recently, Hook et $a l^{6}$ refined the prevalence of structural rearrangements in the newborn to allow for banding. They reviewed structurally abnormal karyotypes ascertained from prenatal diagnoses, determined the proportion that would have gone undetected without banding, and used these data to calculate the prevalence and mutation rates of structural chromosome abnormalities expected in a population of unselected newborns studied with banding techniques.

We decided to use two approaches to calculate the frequency of structural abnormalities that would be detectable using moderate levels of banding in an unselected series of newborns. In the first approach we determined the frequency of structural chromosome abnormalities in a population of conceptuses examined prenatally and, after correction for biases resulting from advanced maternal age, applied the figures obtained to the newborn. In the second approach we adopted the strategy of Hook $e t a l^{6}$ and decided which chromosome abnormalities detected in the prenatal sample using banding techniques would have been missed in the absence of banding. We used the information provided by this assessment to adjust the frequencies of structural abnormalities reported from non-banded surveys of unselected livebirths.

\section{Materials and methods}

The study population consisted of all women aged 35 years or more referred to our laboratory for a prenatal chromosome analysis during the 15 year period 1976 to 1990 (table 1). The great majority of women were studied because of advanced maternal age although the primary referral reason for a minority was advanced maternal age combined with a second reason including a known structural abnormality segregating in the family. In the tabulated data the two populations are shown separately. As we have been studying the chromosomes of the relatively stable population of Wessex since 1967 we felt that the exclusion of the 'known familial structural abnormality' category would result in too low a prevalence rate for structural abnormalities. On the other hand, including them might lead to a spuriously high rate because some of the women, despite being over 35 years of age, might have declined a prenatal examination had they not
Received 15 April 1991 Revised version accepted 24 June 1991. 
been aware of the structural chromosome abnormality present in themselves, their spouse, or a close relative.

From 1976 to 1985 all prenatal diagnoses were done on amniotic fluid specimens, but from 1986 to 1990 a small number of diagnoses were made on cultured (as opposed to direct) chorionic villus samples. While direct preparations of chorionic villi often give rather poor preparations, in our hands the quality of cultured villus samples is very similar to that of cultured amniocytes.

All diagnostic specimens were originally examined on conventional $G$ banded preparations at the 400 to 500 band level. Where an abnormality was seen or suspected other banding techniques such as $\mathrm{C}, \mathrm{Q}$, or DA-DAPI were used where necessary to clarify the nature of the abnormality. Each structural abnormality was assessed independently by at least two observers to determine whether or not it would have been recognised as an abnormality on an unbanded preparation.

The chromosomes of the parents of all abnormalities were examined wherever possible to determine whether the abnormality was inherited or a de novo mutation.

\section{Results}

A total of 112 structural abnormalities was detected among the 14677 prenatal diagnoses giving an overall frequency of $0.76 \%$. While the data for individual years varied from a low of 0 to a high of $1.76 \%$, there was no evidence of a consistent trend with time such as might be expected if the quality of the preparations or the observers had changed in any systematic way (table 1).

The types of structurally abnormal chromosomes ascertained in this population are shown in table 2. Of the 32 unbalanced structural abnormalities, 28 were detected among the prenatal diagnoses done for maternal age alone and four where the ascertainment was maternal age together with another factor. Among the 80 balanced chromosome abnormalities, 71 were ascertained in the advanced maternal age group and nine in the group of advanced maternal age allied to another factor. If it is assumed that the correct prevalence of structural chromosome abnormalities among this population is somewhere between the minimum obtained when we consider only those seen among women ascertained for maternal age alone and the maximum obtained when all women aged 35 or more are included, we have a prevalence of unbalanced abnormalities between $0.197 \%$ and $0.218 \%$ and of balanced abnormalities between $0.499 \%$ and $0.545 \%$. In the remainder of the paper we will consider the rate of abnormalities to be the mean of our minimum and maximum rates, that is $0.208 \%$ for unbalanced and $0.522 \%$ for balanced structural abnormalities.

In table 3 we have shown the number of each type of abnormality in our study that was considered to be detectable with and without banding. As can be seen, it was thought that four of the 32 unbalanced abnormalities and 34 of the 80 balanced structural rearrangements would have been missed in the absence of banding.

The parental origin of the 111 structural abnormalities whose parental chromosome status was known is given in table 4 . As can be seen, 20 of the unbalanced (four excluding the supernumerary category) and 11 of the balanced rearrangements were de novo mutations. In this population the mutation rate for unbalanced rearrangements is $6.8 \times 10^{-4}$ per gamete per generation $\left(1.3 \times 10^{-4}\right.$ excluding the supernumerary category) and $3.7 \times 10^{-4}$ per gamete per generation for balanced rearrangements.

\section{Discussion}

DIRECT COMPARISON OF FREQUENCIES OF STRUCTURAL CHROMOSOME ABNORMALITIES IN THE NEWBORN AND PRENATAL POPULATION

The prenatal population that we studied differs from unselected newborns in at least three respects. First the mothers were all 35 years or more and thus not representative of all reproducing females. However, there is no evidence that parental age plays any role in structural chromosome abnormalities, ${ }^{7}$ with the exception of de novo supernumerary chromosomes, which are much more frequent among the offspring of older women and therefore will be overrepresented in the prenatal sample. ${ }^{8}$ Advanced maternal age should not affect the frequency of any other category of structural

Table 1 The study population.

\begin{tabular}{|c|c|c|c|c|c|c|c|c|}
\hline \multirow[b]{2}{*}{ Year } & \multicolumn{2}{|c|}{ Amniocenteses } & \multicolumn{2}{|c|}{ Chorionic villi } & \multirow{2}{*}{$\begin{array}{l}\text { Total } \\
\text { mat age } \\
\geqslant 35\end{array}$} & \multirow{2}{*}{$\begin{array}{l}\text { Total } \\
\geqslant 35\end{array}$} & \multicolumn{2}{|c|}{ Structural chromosome abnormality } \\
\hline & $\begin{array}{c}\text { Mat age } \\
\geqslant 35\end{array}$ & $\begin{array}{c}\text { Other } \\
\geqslant 35\end{array}$ & $\underset{\geqslant 35}{\text { Mat age }}$ & $\begin{array}{l}\text { Other } \\
\geqslant 35\end{array}$ & & & No & $\%$ \\
\hline $\begin{array}{l}1976 \\
1977 \\
1978 \\
1979 \\
1980 \\
1981 \\
1982 \\
1983 \\
1984 \\
1985 \\
1986 \\
1987 \\
1988 \\
1989 \\
1990\end{array}$ & $\begin{array}{r}167 \\
308 \\
478 \\
455 \\
496 \\
689 \\
826 \\
928 \\
1103 \\
1195 \\
1313 \\
1488 \\
1492 \\
1373 \\
1364\end{array}$ & $\begin{array}{r}8 \\
17 \\
32 \\
28 \\
39 \\
12 \\
16 \\
18 \\
22 \\
23 \\
22 \\
35 \\
57 \\
40 \\
70\end{array}$ & $\begin{array}{l}\overline{-} \\
\overline{-} \\
\overline{-} \\
\overline{-} \\
\overline{-} \\
\overline{-} \\
35 \\
123 \\
141 \\
124 \\
138\end{array}$ & $\begin{array}{l}- \\
- \\
- \\
- \\
- \\
- \\
- \\
- \\
- \\
2 \\
- \\
- \\
-\end{array}$ & $\begin{array}{r}167 \\
308 \\
478 \\
455 \\
496 \\
689 \\
826 \\
928 \\
1103 \\
1195 \\
1348 \\
1611 \\
1633 \\
1497 \\
1502\end{array}$ & $\begin{array}{r}175 \\
325 \\
510 \\
483 \\
535 \\
701 \\
842 \\
946 \\
1125 \\
1218 \\
1372 \\
1646 \\
1690 \\
1537 \\
1572\end{array}$ & $\begin{array}{r}1 \\
- \\
9 \\
5 \\
3 \\
4 \\
9 \\
8 \\
5 \\
7 \\
14 \\
9 \\
18 \\
10 \\
10\end{array}$ & $\begin{array}{l}0.57 \\
0.00 \\
1.76 \\
1.04 \\
0.56 \\
0.57 \\
1.07 \\
0.84 \\
0.44 \\
0.57 \\
1.02 \\
0.54 \\
1.06 \\
0.65 \\
0.64\end{array}$ \\
\hline Total & 13675 & 439 & 561 & 2 & 14236 & 14677 & 112 & $0 \cdot 76$ \\
\hline
\end{tabular}


Table 2 Structural abnormalities by category.

\begin{tabular}{|c|c|c|c|}
\hline \multirow[b]{3}{*}{ Abnormality } & \multicolumn{3}{|c|}{ Ascertainment } \\
\hline & Mat age $\geqslant 35$ & Other $\geqslant 35$ & Total $\geqslant 35$ \\
\hline & No $(\%)$ & No $(\%)$ & No (\%) \\
\hline $\begin{array}{l}\text { Unbalanced } \\
\text { Deletions } \\
\text { Duplications } \\
\text { Rec translocations } \\
\text { Rob translocations } \\
\text { Supernumerary }\end{array}$ & $\begin{array}{r}2 \\
2 \\
1 \\
1 \\
22\end{array}$ & $\begin{array}{l}\overline{-} \\
\overline{3} \\
\overline{1}\end{array}$ & $\begin{array}{r}2 \\
2 \\
4 \\
1 \\
23\end{array}$ \\
\hline Total & $28(0 \cdot 197)$ & $4(0.907)$ & $32(0.218)$ \\
\hline $\begin{array}{l}\text { Balanced } \\
\text { Rec translocations } \\
\text { Rob translocations } \\
\text { Inv paracentric } \\
\text { Inv pericentric } \\
\text { Inv }(Y)\end{array}$ & $\begin{array}{r}34 \\
15 \\
10 \\
11 \\
1\end{array}$ & $\begin{array}{l}5 \\
3 \\
-1 \\
-\end{array}$ & $\begin{array}{r}39 \\
18 \\
10 \\
12 \\
1\end{array}$ \\
\hline Total & $71(0.499)$ & $9(2.041)$ & $80(0.545)$ \\
\hline
\end{tabular}

Table 3 Proportion of structural abnormalities whose detection requires banding.

\begin{tabular}{lccc}
\hline & & \multicolumn{2}{c}{ Require banding for detection } \\
\cline { 3 - 4 } Abnormality & Total & No & $\%$ \\
\hline Unbalanced & 2 & 2 & 100 \\
Deletions & 2 & 1 & 50 \\
Duplications & 4 & 1 & 25 \\
Rec translocations & 1 & 0 & 0 \\
Rob translocations & 23 & 4 & 0 \\
Supernumerary & 32 & 4 & $12 \cdot 5$ \\
Total & 9 & & $44 \cdot 4$ \\
Total excluding supernumerary & & 16 & \\
Balanced & 39 & 0 & $41 \cdot 0$ \\
Rec translocations & 18 & 8 & 0 \\
Rob translocations & 10 & 0 & $66 \cdot 7$ \\
Inv paracentric & 12 & 34 & 0 \\
Inv pericentric & 1 & 34 & $42 \cdot 5$ \\
Inv (Y) & 80 & & $43 \cdot 0$ \\
Total & 79 & & \\
Total excluding inv (Y) & & & \\
\hline
\end{tabular}

abnormality. Secondly, the population we have sampled is in the first (chorionic villi) or second (amniocentesis) trimester of pregnancy. Any structural rearrangements that are selectively lost between the sampling time and birth will result in an inflated prevalence in the fetal sample by comparison with the newborn sample. However, such selective loss is likely to be restricted to pregnancies with an unbalanced chromosome complement or those with a de novo balanced rearrangement associated with an abnormal phenotype. Thirdly, the prenatal observations are made on amniocytes or mesenchymal cells from the chorionic villi, while the newborn observations are made on lymphocytes from peripheral or cord blood. However, the proportion of conceptions in which the chromosome constitution of the prenatal sample does not correspond to that of the fetus proper is considerably less than $1 \%$ and the difference in tissues examined should not therefore lead to any significant bias in the comparisons. $^{9}$

We have compared the prevalence of structural chromosome abnormalities in the nonbanded newborn surveys, the banded newborn surveys, and our prenatal data. The unbanded rates are based on table 1 of Hook and Hamerton $^{1}$ to which we have made a number of adjustments. The modified data are given in table 5 and they differ from those of Hook and Hamerton $^{1}$ in the following respects: (1) six unbalanced $\mathrm{Y} ; 15$ translocations and one $\mathrm{Yq}$ deletion have been removed as they appear to be variants rather than translocations; (2) all additional rings and marker chromosomes have been scored as supernumerary chromosomes; (3) mosaics have been separately identified; and (4) all inverted $\mathrm{Y}$ chromosomes have been enumerated as structural abnormalities but given a special category, as it is controversial whether they should be regarded as abnormalities or as variant chromosomes. The banded newborn data are the pooled results of the four published surveys with two adjustments: (1) the nature of the two autosomal inversions in the survey of Nielsen $e t a l^{4}$ was not specified and we have arbitrarily assigned one to the paracentric and one to the pericentric category; and (2) the unbalanced Y;15 translocation reported by Buckton et $a l^{3}$ has been removed as it appeared to be a variant rather than a translocation.

As can be seen from table 6, after exclusion of the supernumerary category, there is a twofold increase in unbalanced abnormalities detected in the prenatal population by comparison with the unbanded or banded newborn populations. Among the balanced abnormalities, after exclusion of the inverted $\mathrm{Y}$ category, there is a $50 \%$ increase in the number of structural abnormalities detected in the

Table 4 Parental origin of structural abnormalities.

\begin{tabular}{|c|c|c|c|c|c|}
\hline \multirow[b]{2}{*}{ Abnormality } & \multicolumn{3}{|c|}{ Origin } & \multirow[b]{2}{*}{ Total } & \multirow{2}{*}{$\begin{array}{c}\text { Mutation } \\
\text { rate } \\
\left(\times 10^{-4}\right)\end{array}$} \\
\hline & Paternal & Maternal & De novo & & \\
\hline $\begin{array}{l}\text { Unbalanced } \\
\text { Deletions } \\
\text { Duplications } \\
\text { Rec translocations } \\
\text { Rob translocations } \\
\text { Supernumerary }\end{array}$ & $\begin{array}{l}0 \\
0 \\
0(+1)^{*} \\
0 \\
2\end{array}$ & $\begin{array}{l}0 \\
1 \\
1(+2) \\
0 \\
4(+1)\end{array}$ & $\begin{array}{r}2 \\
1 \\
0 \\
1 \\
16\end{array}$ & $\begin{array}{r}2 \\
2 \\
4 \\
1 \\
23\end{array}$ & $\begin{array}{l}1 \cdot 0 \\
\\
0 \cdot 3 \\
5 \cdot 5\end{array}$ \\
\hline Total & $2(+1)$ & $6(+3)$ & 20 & 32 & $6 \cdot 8$ \\
\hline $\begin{array}{l}\text { Balanced } \\
\text { Rec translocations } \\
\text { Rob translocations } \dagger \\
\text { Inv paracentric } \\
\text { Inv pericentric } \\
\text { Inv }(Y)\end{array}$ & $\begin{array}{c}11(+3) \\
6 \\
3 \\
6 \\
1\end{array}$ & $\begin{array}{l}15(+2) \\
6(+3) \\
6 \\
6 \\
0\end{array}$ & $\begin{array}{l}8 \\
2 \\
1 \\
0 \\
0\end{array}$ & $\begin{array}{r}39 \\
17 \\
10 \\
12 \\
1\end{array}$ & $\begin{array}{l}2 \cdot 7 \\
0.7 \\
\\
0 \cdot 3\end{array}$ \\
\hline Total & $27(+3)$ & $33(+5)$ & 11 & 79 & $3 \cdot 7$ \\
\hline
\end{tabular}

* Figures in parentheses indicate cases ascertained because of known parental structural chromosome abnormality.

† The parental chromosomes were not examined in one patient with a Robertsonian translocation. 
Table 5 Chromosome abnormalities in newborn babies (unbanded) (adapted from Hook and Hamerton ${ }^{\prime}$ ).

\begin{tabular}{|c|c|c|c|c|c|c|}
\hline \multirow[b]{2}{*}{$\begin{array}{l}\text { Category } \\
\text { (No) }\end{array}$} & \multicolumn{3}{|c|}{ Abnormality } & \multirow[b]{2}{*}{ Total } & \multicolumn{2}{|c|}{ Percentage } \\
\hline & Type & Pure & Mosaic & & $\begin{array}{c}\text { Sex } \\
\text { specific }\end{array}$ & $\begin{array}{c}\text { All } \\
\text { births }\end{array}$ \\
\hline \multirow[t]{2}{*}{$\begin{array}{l}\text { Sex } \\
\text { chromosome } \\
\text { males (37 779) }\end{array}$} & $\begin{array}{l}47, X Y Y \\
47, X X Y \\
\text { Other* }\end{array}$ & $\begin{array}{r}35 \\
35 \\
3\end{array}$ & $\begin{array}{l}8 \\
5 \\
1\end{array}$ & $\begin{array}{r}43 \\
40 \\
4\end{array}$ & $\begin{array}{l}0 \cdot 114 \\
0 \cdot 106 \\
0.011\end{array}$ & $\begin{array}{l}0.057 \\
0.053 \\
0.005\end{array}$ \\
\hline & Total & 73 & 14 & 87 & $0 \cdot 230$ & $0 \cdot 115$ \\
\hline \multirow{2}{*}{$\begin{array}{l}\text { Sex } \\
\text { chromosome } \\
\text { females }(19173)\end{array}$} & $\begin{array}{l}45, \mathrm{X} \\
47, \mathrm{XXX}\end{array}$ & $\begin{array}{r}2 \\
20\end{array}$ & $\begin{array}{l}7 \dagger \\
-\end{array}$ & $\begin{array}{r}9 \\
20\end{array}$ & $\begin{array}{l}0 \cdot 047 \\
0 \cdot 104\end{array}$ & $\begin{array}{l}0.023 \\
0.052\end{array}$ \\
\hline & Total & 22 & 7 & 29 & $0 \cdot 151$ & 0.075 \\
\hline \multirow[t]{2}{*}{$\begin{array}{l}\text { Autosomal } \\
\text { trisomy } \\
(56952)\end{array}$} & $\begin{array}{l}\text { D } \\
\text { E } \\
\text { G } \\
\text { Other }+\end{array}$ & $\begin{array}{r}3 \\
7 \\
71 \\
1\end{array}$ & $\begin{array}{l}- \\
- \\
- \\
-\end{array}$ & $\begin{array}{r}3 \\
7 \\
71 \\
1\end{array}$ & & $\begin{array}{l}0.005 \\
0.012 \\
0.125 \\
0.002\end{array}$ \\
\hline & Total & 82 & 0 & 82 & & $0 \cdot 144$ \\
\hline \multirow[t]{2}{*}{$\begin{array}{l}\text { Structural } \\
\text { abnormality } \\
\text { unbalanced } \\
(56952)\end{array}$} & $\begin{array}{l}\text { Deletions } \\
\text { Duplications } \S \\
\text { Rec translocations } \\
\text { Rob translocations } \\
\text { Supernumerary }\end{array}$ & $\begin{array}{r}5 \\
1 \\
1 \\
4 \\
10\end{array}$ & $\begin{array}{l}1 \\
1 \\
0 \\
0 \\
6\end{array}$ & $\begin{array}{r}6 \\
2 \\
1 \\
4 \\
16\end{array}$ & & $\begin{array}{l}0.011 \\
0.004 \\
0.002 \\
0.007 \\
0.028\end{array}$ \\
\hline & Total & 21 & 8 & 29 & & 0.052 \\
\hline \multirow[t]{2}{*}{$\begin{array}{l}\text { Structural } \\
\text { abnormality } \\
\text { balanced } \\
(56952)\end{array}$} & $\begin{array}{l}\text { Rec translocations } \\
\text { Rob translocations } \\
\text { Inv paracentric } \\
\text { Inv pericentric } \\
\text { Inv }(Y)\end{array}$ & $\begin{array}{r}51 \\
51 \\
\overline{8} \\
10\end{array}$ & $\begin{array}{l}- \\
\overline{-} \\
\overline{-} \\
-\end{array}$ & $\begin{array}{r}51 \\
51 \\
\overline{8} \\
10\end{array}$ & & $\begin{array}{l}0.090 \\
0.090 \\
-\overline{-} \\
0.014 \\
0.018\end{array}$ \\
\hline & Total & 120 & 0 & 120 & & $0 \cdot 212$ \\
\hline All abnormalities & & & & & & 0.598 \\
\hline
\end{tabular}

banded newborn studies and a twofold to threefold increase in the prenatal sample by comparison with the non-banded newborn population.

\section{INDIRECT CALCULATIONS OF FREQUENCIES OF STRUCTURAL CHROMOSOME ABNORMALITIES IN THE NEWBORN}

Hook et $a l^{6}$ adopted a different approach to refining the newborn estimates of structural abnormalities. They reviewed 226 structural abnormalities detected among prenatal diagnosis using moderate levels of banding (300 to 400 bands) and estimated the proportion that would have been missed in the absence of banding. This method of correcting the newborn data has the advantage that it should be free of bias introduced by selective loss of fetuses with a structural chromosome abnormality between the time of chromosome analysis and birth. However, it has the disadvantages of (1) relying on the opinions of observers as to whether or not banding was essential for detection of a particular abnormality and (2) not providing any estimate for categories of abnormalities, such as paracentric inversions, that are completely absent from non-banded preparations. We have adopted a similar approach to that of Hook et al. ${ }^{6}$ As can be seen from table 3 , we estimated that $44.4 \%$ of unbalanced rearrangements, excluding

Table 6 Comparison of structural abnormality rates in unbanded and banded newborn surveys, the prenatal population both direct and adjusted, and adjusted by estimates of Hook et al. ${ }^{6}$

\begin{tabular}{|c|c|c|c|c|c|}
\hline Abnormality & $\begin{array}{c}\text { Newborn, } \\
\text { non-banded } \\
(\mathrm{n}=56952) \\
(\%)\end{array}$ & $\begin{array}{c}\text { Newborn, } \\
\text { banded } \\
(\mathrm{n}=10253) \\
(\%)\end{array}$ & $\begin{array}{c}\text { Prenatal, } \\
\text { direct } \\
(\mathrm{n}=14677) \\
(\%)\end{array}$ & $\begin{array}{c}\text { Newborn, } \\
\text { non-banded. } \\
\text { Adjusted by } \\
\text { estimates } \\
\text { calculated } \\
\text { in this study } \\
(\%)\end{array}$ & $\begin{array}{c}\text { Newborn, } \\
\text { non-banded. } \\
\text { Adjusted by } \\
\text { estimates of } \\
\text { Hook et } \text { al }^{6} \\
(\%)\end{array}$ \\
\hline $\begin{array}{l}\text { Unbalanced } \\
\text { Deletions } \\
\text { Duplications } \\
\text { Rec translocations } \\
\text { Rob translocations } \\
\text { Supernumerary }\end{array}$ & $\begin{array}{l}0.011 \\
0.004 \\
0.002 \\
0.007 \\
0.028\end{array}$ & $\begin{array}{c}\overline{0.020} \\
\overline{-} \\
0 . \overline{088}\end{array}$ & $\begin{array}{l}0.014 \\
0.014 \\
0.017 \\
0.007 \\
0.156\end{array}$ & $\begin{array}{l}0.026 \\
\\
0.007 \\
0.028\end{array}$ & $\begin{array}{l}0.020 \\
\\
0.007 \\
0.028\end{array}$ \\
\hline $\begin{array}{l}\text { Total } \\
\text { Total excluding supernumerary }\end{array}$ & $\begin{array}{l}0.052 \\
0.024\end{array}$ & $\begin{array}{l}0 \cdot 108 \\
0.020\end{array}$ & $\begin{array}{l}0 \cdot 208 \\
0.052\end{array}$ & $\begin{array}{l}0.061 \\
0.033\end{array}$ & $\begin{array}{l}0.055 \\
0.027\end{array}$ \\
\hline $\begin{array}{l}\text { Balanced } \\
\text { Rec translocations } \\
\text { Rob translocations } \\
\text { Inv paracentric } \\
\text { Inv pericentric } \\
\text { Inv }(Y)\end{array}$ & $\begin{array}{l}0.090 \\
0.090 \\
-\overline{0} \\
0.014 \\
0.018\end{array}$ & $\begin{array}{l}0.166 \\
0.098 \\
0.010 \\
0.029 \\
0.049\end{array}$ & $\begin{array}{l}0 \cdot 253 \\
0 \cdot 114 \\
0 \cdot 068 \\
0 \cdot 080 \\
0 \cdot 007\end{array}$ & $\begin{array}{l}0.152 \\
0.090 \\
-\overline{0} \\
0.042 \\
0.018\end{array}$ & $\begin{array}{l}0.185 \\
0.090 \\
-\overline{06} \\
0.018 \\
0.018\end{array}$ \\
\hline Total & 0.212 & 0.352 & 0.522 & 0.302 & $0 \cdot 355$ \\
\hline Total excluding inv $(\mathrm{Y})$ & 0.194 & 0.303 & 0.515 & 0.284 & $0 \cdot 337$ \\
\hline
\end{tabular}


supernumeraries, and $43 \%$ of balanced rearrangements would have been missed in the absence of banding, the corresponding figures of Hook et $a l^{6}$ being $22 \%$ and $47 \%$.

In table 6 we have shown the data for the prevalence of structural rearrangements among the newborn using both our own adjustment factors and those of Hook et al. ${ }^{6}$ We are in substantial agreement that among unbalanced abnormalities the rates would increase from approximately $0.05 \%$ to $0.06 \%$, while among balanced rearrangements, the rate would increase from approximately $0 \cdot 20 \%$ to $0.30 \%$.

COMPARISON OF THE TWO METHODS

While our adjusted estimates for structural abnormalities are comparable to those of Hook et $a l^{6}$ using a similar methodology, they are considerably lower than our estimates based on a direct 'upgrading' of the newborn data by those from the prenatal material. Thus, after excluding supernumeraries, we have a frequency of $0.052 \%$ of unbalanced abnormalities among the prenatal specimens and only $0.033 \%$ when our adjusted estimates are used. There are two possible reasons for the discrepancy; first, that there is a considerable loss of pregnancies with an unbalanced structural abnormality between the time of prenatal diagnosis and birth, and secondly that we underestimated the proportion of unbalanced rearrangements that require banding to identify them. The former explanation seems plausible, and we therefore consider our adjusted estimate to be the more realistic for unbalanced structural abnormalities detected in the newborn using moderate levels of banding.

When the balanced rearrangements are considered, their frequency in prenatal material is about twice their frequency in our adjusted estimates even after the removal of the inverted $Y$ and paracentric inversion categories which are not represented in the adjusted estimates. Furthermore, both our adjusted estimate and that of Hook et $a l^{6}$ are very similar to the frequencies seen in the newborn banded preparations. Again, the excess in the prenatal material could be the result of selective loss between sampling and birth or our underestimation of the proportion of balanced rearrangements that need banding for their detection or both. If selective loss of balanced rearrangements occurs at all, it is only likely to involve de novo structural abnormalities associated with an abnormal phenotype. In order to see whether there was an excess of de novo

Table 7 The estimated frequency of chromosome abnormalities in a population of unselected newborns using moderate levels of banding.

\begin{tabular}{lcc}
\hline Abnormality & $\begin{array}{c}\text { All abnormalities } \\
(\%)\end{array}$ & $\begin{array}{c}\text { De novo } \\
\text { abnormalities } \\
(\%)\end{array}$ \\
\hline Sex chromosome: male & 0.115 & 0.115 \\
Sex chromosome: female & 0.075 & 0.075 \\
Autosome trisomy & 0.142 & 0.142 \\
Structural abnormality: unbalanced & 0.061 & 0.038 \\
Structural abnormality: balanced & 0.522 & 0.073 \\
Triploidy & 0.002 & 0.002 \\
Total & 0.917 & 0.445 \\
\hline
\end{tabular}

structural abnormalities in the prenatal specimens by comparison with the newborn we compared the mutation rates in our population (table 4) with those given by Hook et $a l^{6}$ based on the data of Jacobs. ${ }^{10}$ The data are very similar. Hook et $a l^{6}$ obtained a gametic mutation rate of $3.5 \times 10^{-4}$ for balanced rearrangements, excluding paracentric inversions, while we obtained a rate of $3.7 \times 10^{-4}$ including paracentric inversions and $3.4 \times 10^{-4}$ excluding paracentric inversions. Therefore the increased frequency of balanced rearrangements among the prenatal specimens does not appear to be attributable to loss of de novo balanced rearrangements before birth. This increase must therefore result from an underestimate of the proportion of balanced aberrations that need banding to be identified, both in our series and that of Hook et al. ${ }^{6}$

Although our estimates agree rather well with the newborn banded surveys, these were done in the relatively early years of banding and may well be an underestimate of what can be seen by experienced observers used to analysing banded material. Therefore, we believe that the most realistic estimate of balanced abnormalities detectable in banded series of unselected newborns is that given by the prenatal data.

In table 7 we have given our best estimate of the rate of chromosome abnormalities detectable in an unselected series of newborn babies using a moderate level of banding. For the non-structural abnormalities we have used the amended data of Hook and Hamerton ${ }^{1}$ given in table 5 in this paper, while for the unbalanced structural rearrangements we have used our own adjusted estimates, and for the balanced rearrangements the data from our prenatal observations. As can be seen, the use of only moderate levels of banding increases the frequency of abnormalities detectable in the newborn from $0.598 \%$ to $0.917 \%$. When comparisons are made between frequencies of chromosome abnormalities in specific populations studied using banding techniques and those seen in unselected newborns, it is essential that estimates are used, such as those provided in this paper, that are adjusted to allow for the appropriate levels of banding.

We are extremely grateful to Sheila Youings for her help in collating the data and to all the members of the laboratory, both past and present, who carried out the cytogenetic analyses. We also thank Judy Gladding for her help with the manuscript.

1 Hook EB, Hamerton JL. The frequency of chromosome abnormalities detected in consecutive newborn studies abnormalities differences between studies - results by sex and by severity of phenotypic involvement. In: Hook EB, Porte IH, eds. Population cytogenetics. New York State Department of Health, Birth Defects Institute, Symposium (1975), Albany, New York, October 1975. New York: Academic
Press, 1977:63.

2 Lin CC, Gedeon MM, Griffith P, et al. Chromosome analysis on 930 consecutive newborn children using quinacrine fluorescent banding technique. Hum Gene 1976;31:315-28.

3 Buckton KE, O'Riordan ML, Ratcliffe S, Slight J, Mitchell M, McBeath S. A G-band study of chromosomes in liveborn infants. Ann Hum Genet 1980;43:227-39.

4 Nielsen J, Wohlert M, Faaborg-Andersen J, et al. Incidence of chromosome abnormalities in newborn children. Comparison between incidences in 1969-1974 and 1980-1982 in the same area. Hum Genet 1982;61:98-101. 
5 Hansteen I-L, Varslot K, Steen-Johnsen J, Langard S. Cytogenetic screening of a new-born population. Clin Genet 1982;21:309-14

6 Hook EB, Healy N, Willey A. How much difference does chromosome banding make? Ann Hum Genet 1989;54:237-42.

7 Olson SB, Magenis RE. Preferential paternal origin of de novo structural chromosome rearrangements. In Daniels A, ed. The cytogenetics of mammalian autosome rearrangements. New York: Alan R Liss, 1988:583.
8 Hook EB, Schreinemachers DM, Willey AM, Cross PK. Rates of mutant structural chromosome rearrangements in human fetuses: data from prenatal cytogenetic studie and associations with maternal age and parental mutagen exposure. Am f Hum Genet 1983;35:96-109.

9 Hsu LYF, Perlis TE. United States survey on chromosome mosaicism and pseudomosaicism in prenatal diagnosis. Prenat Diagn 1984;4:97-130.

10 Jacobs P. Mutation rates of structural chromosome re arrangements in man. Am f Hum Genet 1981;33:44-54. 